\title{
Assessment of genetic diversity and distance of three Cicuta virosa populations in South Korea
}

\author{
Bo Eun Nam ${ }^{1}$, Jae Geun Kim ${ }^{1, *}$ and Cha Jeong Shin ${ }^{2}$ \\ ${ }^{1}$ Department of Biology Education, Seoul National University, Seoul 151-748, Korea \\ ${ }^{2}$ Busan Nam High School, Busan 606-809, Korea
}

\begin{abstract}
Cicuta virosa L. (Apiaceae) is a perennial emergent plant designated as an endangered species in South Korea. According to the former records, only four natural habitats remain in South Korea. A former study suggested that three of four populations (Pyeongchang: PC, Hoengseong: HS, Gunsan: GS) would be classified as different ecotypes based on their different morphological characteristics and life cycle under different environmental conditions. To evaluate this suggestion, we estimated genetic diversity in each population and distance among three populations by random amplification of polymorphic DNA. Seven random primers generated a total of 61 different banding positions, 36 (59\%) of them were polymorphic. Nei's gene diversity and the Shannon diversity index increased in the order of $\mathrm{PC}<\mathrm{HS}<\mathrm{GS}$, which is the same order of population size. In the two-dimensional (2D) plot of first two principal components in principal component analysis with the presence of 61 loci, individuals could be grouped as three populations easily (proportion of variance $=0.6125$ ). Nei's genetic distance for the three populations showed the same tendency with the geographical distance within three populations. And it is also similar to the result of discriminant analysis with the morphological or life-cycle factors from the previous study. From the results, we concluded that three different populations of $C$. virosa should be classified as ecotypes based on not only morphology and phenology but genetic differences in terms of diversity and distance as well.
\end{abstract}

Keywords: ecotype, genetic distance, RAPD, water hemlock

\section{INTRODUCTION}

Cicuta virosa L. (Apiaceae) is a perennial emergent plant that has toxic substance (cicutoxin) in its roots and tubers (Panter et al. 1988). It disperses by its overwintering rootstocks or buoyant fruits (Mulligan and Munro 1981). Natural populations of $C$. virosa were found at north and central Europe, northern Asia, northern America (Fig. 1a, Mulligan and Munro 1981, Lee 2003). South Korea is a southern marginal area of distribution, population size of $C$. virosa has decreased (Shin et al. 2013). Under the experimental condition with elevated $\mathrm{CO}_{2}$ concentration and temperature according to the general climate change scenario, the timing of flowering, flower stalk forming and seed formation were earlier than the control condition and germination rate of self-pollinated seeds were higher at experimental condition (Hong 2012). Therefore, longterm climate change seems to be able to affect the phenology of C. virosa. Several countries (e.g., Japan, Hungary) have designated $C$. virosa as a protected species (Tatar 2010, Japanese Wildlife Research Association 2012), and C. virosa also has been designated as a domestic endangered species in Korea (Korea National Arboretum 2012).

Former studies about $C$. virosa mainly have concentrat-

\section{Open Access http://dx.doi.org/10.5141/ecoenv.2013.205}

This is an Open Access article distributed under the terms of the Creative Commons Attribution Non-Commercial License (http://creativecommons org/licenses/by-nc/3.0/) which permits unrestricted non-commercial use distribution, and reproduction in any medium, provided the original work is properly cited.
Received 05 August 2013, Accepted 08 September 2013

*Corresponding Author

E-mail: jaegkim@snu.ac.kr

Tel: +82-2-880-7896 


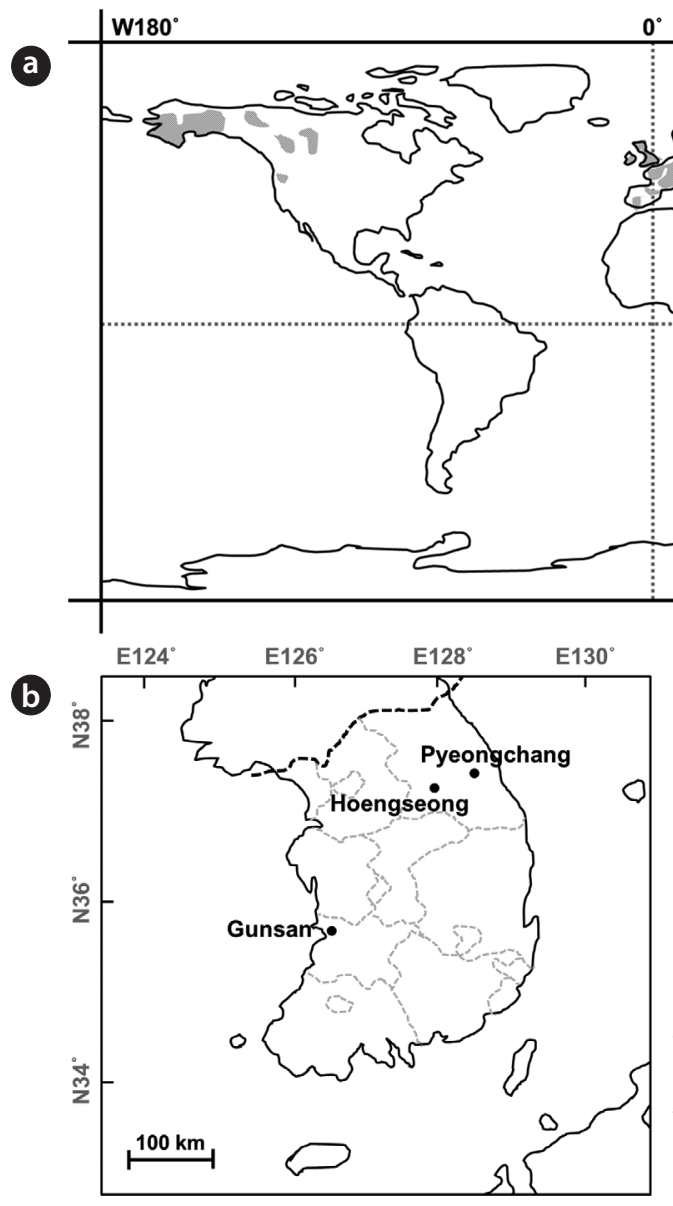

ed on toxicology or pharmacology of cicutoxin (Sarreveld and Hope 1975, Strauß et al. 1996). C. virosa requires wet substrate and this requirement limits its habitat range such as streams, ditches, lakes, rivers or marshy areas (Panter et al. 1988). In South Korea, only four natural habitats of C. virosa were remained and their water and soil conditions were similar to the optimal environmental range of their accompanying species. However, only the water level was different from optimal range of others (Shin et al. 2013). Three of four populations in Korea (except the smallest and rapidly decreasing population) were suggested to be classified as different ecotypes based on their different morphological characteristics and phenology under different environmental conditions (Shin and Kim 2013).

Understanding of the genetic structure of vulnerable species is important to formulate sustainable conservation strategy (Ellstrand and Elam 1993, Lee et al. 2004, Kim et al. 2008). Several molecular analysis tools, such as DNA sequencing, random amplification of polymorphic DNA
(RAPD), inter simple sequence repeat (ISSR), and amplified fragment length polymorphism (AFLP) has been utilized in ecological studies (Beebee and Graham 2008). To study the genetic difference among three populations, we used the RAPD method that has been used for investigating the genetic diversity and structure of populations and that is independent to the former knowledge of their DNA sequence (Williams et al. 1990, Newbury and Ford-Lloyd 1993, Beebee and Graham 2008). This method has been used for understanding the formation and maintenance of natural plant populations (Bonnin et al. 1996, Min et al. 2012), intraspecific phylogenic studies (Kim et al. 2008, Ok and Yoo 2012), and genetic difference among the varieties or ecotypes (Virk et al. 1995, Ray and Roy 2009, Arghavani et al. 2010).

The aim of this study is to assess the genetic diversity within three C. virosa populations in Korea and the differences among them using RAPD markers and to understand the relationship between the genetic difference and ecotypic differences of Shin and Kim (2013). The sugges- 
tion to classify the three C. virosa populations as ecotypes would be able to be supported with the result of this study of the genetic difference.

\section{MATERIALS AND METHODS}

\section{Sampling sites and populations description}

Only four natural habitats of C. virosa were reported in South Korea and sampling was conducted at three of the four habitats (Fig. 1b). Pyeongchang (PC) was a wet meadow that located at $793 \mathrm{~m}$ above sea level, and accompanying species with C. virosa was Scirpus radicans. At Hoengseong (HS), two subpopulations (12-year-old abandoned paddy field and streamlet) were located with about $700 \mathrm{~m}$ distance. Persicaria thunbergii was a major accompanying species at the abandoned paddy field and Phragmites japonica at the streamlet. Gunsan (GS) was a reservoir which located at relatively low latitude than PC and HS. C. virosa has been lived on the floating mat with Zizania latifolia and Paspalum distichum. The major accompanying species at GS was Z. latifolia. Population sizes in PC, the abandoned paddy field at HS, streamlet at HS and GS were $<40,170,70,>500$, respectively (see Shin et al. 2013 for detailed description). Population in Gangneung was excluded for sampling because of its small population size $(<10)$.

\section{Seed sampling and germination}

At the year of 2012, after the flowering time of each three populations, seeds of the senescent $C$. virosa individuals were collected randomly from more than 5 individuals. Seeds were stored at $4^{\circ} \mathrm{C}$ until the germination. Collected seeds were germinated in a growth chamber, on the wet filter paper in petri dishes. Each cycle of light and temperature condition was kept in 12 hours interval, light (at $30^{\circ} \mathrm{C}$ ) and dark (at $15^{\circ} \mathrm{C}$ ) for a week.

\section{RAPD-PCR}

After about a week from the germination, five seedlings were randomly collected in each of three populations. Each sample size of them was determined in previous studies about the distinction among ecotypes using RAPD markers (Milella et al. 2006, Ray and Roy 2009, Arghavani et al. 2010). Whole genomic DNA extraction was followed with DNeasy Plant Mini Kit (Qiagen, Hilden, Germany) according to manufacturer's protocol.

PCR for RAPD analysis was conducted with AccuPower PCR premix (Bioneer, Daejeon, South Korea). Total reaction volume of PCR was $20 \mu \mathrm{L}$, composed of $1 \mu \mathrm{L}$ of DNA extracted from each seedling, $1 \mu \mathrm{L}$ of primer $(10 \mathrm{pmol})$, and $18 \mu \mathrm{L}$ of deionized water. Seven of 33 random primers (Bioneer) which showed the polymorphism in electrophoresis were selected for RAPD analysis (Table 1). Reaction cycle of PCR began with the 2 min of denaturation at $94^{\circ} \mathrm{C} .40$ cycles were followed with $45 \mathrm{~s}$ of denaturation at $94^{\circ} \mathrm{C}, 45 \mathrm{~s}$ of annealing at the $\mathrm{T}_{\mathrm{m}}$ of each primer, and $1 \mathrm{~min}$ $30 \mathrm{~s}$ of elongation at $72^{\circ} \mathrm{C}$. Lastly, $2 \mathrm{~min}$ of the final extension step at $72^{\circ} \mathrm{C}$ was followed.

Electrophoresis of amplified fragments was conducted in $1 \%$ agarose gel stained with GelRed ${ }^{\mathrm{TM}}$ (Biotium, Heyward, CA, USA). Under the UV light, bands were observed and recorded by binary character matrix with 1 (presence) and 0 (absence).

\section{Data analysis}

Genetic diversity within the population (number of polymorphic loci, Nei's gene diversity: h, Shannon index: i), genetic distance (Nei's genetic distance) among populations and unweighted pair-group method with arith-

Table 1. Random primer sequences and number of amplified RAPD fragments

\begin{tabular}{cccc}
\hline Oligonucleotide Name & Sequence & Tm $\left({ }^{\circ} \mathbf{C}\right)$ & No. of observed band loci \\
\hline N-8001 & CAGGCCCTTC & 34 & $7\left(3^{*}\right)$ \\
N-8002 & CAATCGCCGT & 32 & $8\left(5^{*}\right)$ \\
N-8004 & TCGGCGATAG & 32 & $11\left(9^{*}\right)$ \\
N-8005 & GAAACGGGTG & 32 & $12\left(4^{*}\right)$ \\
N-8010 & CTGAGACGGA & 32 & $5\left(3^{*}\right)$ \\
N-8075 & GAGGTCCACA & 32 & $9\left(4^{*}\right)$ \\
N-8078 & GTGTGCCGTT & 32 & $9\left(8^{*}\right)$ \\
\hline
\end{tabular}

"Number in the parenthesis is the number of polymorphic bands for each primer. 
metic averages (UPGMA) dendrogram were calculated by Popgen 32 with the binary matrix data (Yeh and Boyle 1997). Principal component analysis (PCA) with presence and absence of each band was conducted by $\mathrm{R}$ ver. 2.15.0 (R Development Core Team 2013).

\section{RESULT AND DISCUSSION}

\section{Genetic diversity among individuals of three populations}

61 band loci were detected from seven random primers and 36 loci (59\%) of them were shown to be polymorphic. 10 (28\%) of 36 polymorphic loci appeared only one or two populations. DNA sequence of these specific loci could be able to design the population-specific markers (Ray and Roy 2009).

In three populations, average of Nei's gene diversity (h) was 0.0747 , and it of Shannon index (i) was 0.1115 . GS was shown to be the highest gene diversity (Table 2).

In GS, the population size of C. virosa in 2011 over 500 individuals was largest in three populations. Population sizes of it at abandoned paddy field and Narrow streamlet of HS were about 170 and 70, respectively. PC has the smallest size, less than 40 individuals (Shin et al. 2013). Genetic diversity of the randomly selected seeds from three $C$. virosa populations also seems to be affected by their population size at natural habitat (Ellstrand and Elam 1993, Frankham 1996, Fischer et al. 2000, Kim et al. 2008).

From the result of PCA with band presence and absence of 61 loci, 5 principal components had $83 \%$ of total variance and proportion of variance of major 9 principal components was $95 \%$. On the 2D plot of major two principal components ( $\mathrm{PC} 1, \mathrm{PC} 2)$, three populations were clearly separated and grouped within each population (Fig. 2). This result implies that three populations could be grouped based on the RAPD-PCR results.

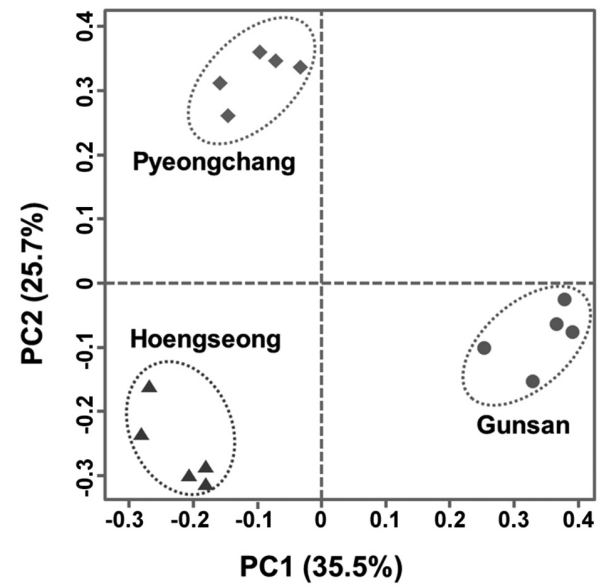

Fig. 2. 2D plot of principal component analysis (PCA) of 15 seedlings with presence and absence of 61 band loci. 15 individuals are plotted at the first two principal components.

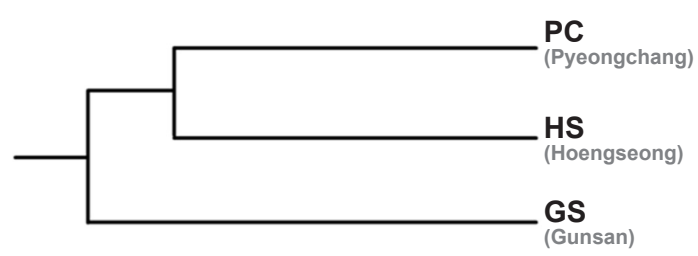

Fig. 3. UPGMA dendrogram based on Nei's genetic distance for the three populations of Cicuta virosa. Nei's genetic distances were PC-HS = $0.1999, \mathrm{PC}-\mathrm{GS}=0.2331$, and HS-GS $=0.2618$.

\section{Genetic distance among three populations}

Genetic distance among three populations based on Nei's genetic distance was the highest between HS and GS (0.2618). The shortest distance was between PC and HS (0.1999), and the distance between PC and GS was 0.2331. GS seems to be genetically apart from PC and HS in the UPGMA dendrogram from the RAPD markers (Fig. 3).

$\mathrm{PC}$ and HS are located in Gangwon province, the eastern part of Korean peninsula, whereas GS is located in Jeollabuk province, adjacent to the western sea of Korea

Table 2. Number of polymorphic loci and percentage, Nei's gene diversity (h), and Shannon index (i) in three populations

\begin{tabular}{ccccc}
\hline Population & $\begin{array}{c}\text { No. of } \\
\text { polymorphic loci (\%) }\end{array}$ & $\begin{array}{c}\text { No. of } \\
\text { specific band loci }\end{array}$ & h \\
\hline PC & $12(19.7)$ & 2 & 0.0646 & 0.0985 \\
HS & $12(19.7)$ & 3 & 0.0674 & 0.1016 \\
GS & $14(23.0)$ & 5 & 0.0920 & 0.1343 \\
Total $^{*}$ & $36(59.0)$ & 10 & 0.2020 & 0.3005 \\
\hline
\end{tabular}

"Total does not mean the sum of polymorphic loci numbers of three populations but the total loci number which considers overlapped loci among populations. 
and the reservoir is located on relatively lower latitude than PC and HS. Straight-line distances between PC and HS, PC and GS, HS and GS are about $50 \mathrm{~km}, 261 \mathrm{~km}$ and $218 \mathrm{~km}$, respectively. Genetic distance among populations could be increased similar to the increasing of the geographic distance when genetic flow among populations and genetic drift in each population make equilibrium (Hutchinson and Templeton 1999). Based on the genetic and geographic distance among three populations, GS seems they had been separated earlier from the common ancestor than the other two populations.

Ecotypic characteristics such as seed length and weight, flowering time, and sensitivity about the moisture stress were significantly different among three populations (Shin and Kim 2013). However, such as root:shoot (R:S) ratio or relative growth rate (RGR) in length in GS was significantly different from HS and PC, whereas the two populations (HS and PC) were not significantly different from each other. In addition, as a result of a 2D plot of the discriminant analysis, GS was relatively away from HS and PC (Shin and Kim 2013). This result seems to be affected from the genetic distance among three populations.

\section{CONCLUSION}

Based on the RAPD analysis, genetic diversity in each population seems to be affected from their population size and some polymorphic loci appeared only one or two populations. In a result of PCA with the band presence, three populations were separated from each other and grouped within each population on 2D plot. In addition, genetic distance among three populations was associated to their geographic distance and it also corresponds to the Shin and Kim's study (2013) about the morphological and phenological characteristics. In conclusion, we suggest it is possible to distinguish the C. virosa individuals into three populations by the result of RAPD-PCR and this support the suggestion of classifying three populations as different ecotype.

\section{ACKNOWLEDGEMENT}

This study was supported by the Korea Ministry of Environment as "The Eco-Innovation project, 416-111-010" and by the Center for Aquatic Ecosystem Restoration (CAER) of the Eco-STAR project from the Ministry of Environment, Republic of Korea (MOE;08-III-12).

\section{LITERATURE CITED}

Arghavani A, Asghari A, Shokrpour M, Chamanabad M. 2010. Genetic diversity in ecotypes of two Agropyron species using RAPD markers. Res J Environ Sci 4: 50-56.

Beebee T, Graham R. 2008. An Introduction to Molecular Ecology, 2nd ed. Oxford University Press, Oxford.

Bonnin I, Huguet T, Gherardi M, Prosperi JM, Olivieri I. 1996. High level of polymorphism and spatial structure in a selfing plant species, Medicago truncatula (Leguminosae), shown using RAPD markers. Am J Bot 83: 843-855.

Ellstrand NC, Elam DR. 1993. Population genetic consequences of small population size: implications for plant conservation. Ann Rev Ecol Syst 24: 217-242.

Fischer M, Husi R, Prati D, Peintinger M, van Kleunen M, Schmid B. 2000. RAPD variation among and within small and large population of the rare clonal plant Ranunculus reptans (Ranunculaceae). Am J Bot 87: 1128-1137.

Frankham R. 1996. Relationship of genetic variation to population size in wildlife. Conserv Biol 10: 1500-1508.

Global Biodiversity Information Facility. 2013. GBIF data portal. http://data.gbif.org. Accessed 5 September 2013.

Hong YS. 2012. Effects of elevated $\mathrm{CO}_{2}$ concentration and temperature on the phenology, growth response and reproductive ecology of Cicuta virosa, endangered plant in Korea. MS Thesis. Kongju University, Gongju, Korea. (in Korean)

Hutchison DW, Templeton AR. 1999. Correlation of pairwise genetic and geographic distance measures: inferring the relative influences of gene flow and drift on the distribution of genetic variability. Evolution 53: 1898-1914.

Japanese Wildlife Research Association. 2012. In: Search system of Japanese RED data. http://www.jpnrdb.com/ search.php?mode=map\&q=06031083218. Accessed 7 June 2012. (in Japanese)

Kim C, Na HR, Choi HK. 2008. Genetic diversity and population structure of endangered Isoetes coreana in South Korea based on RAPD analysis. Aquat Bot 89: 43-49.

Korea National Arboretum. 2012. Korea biodiversity information system. http://www.nature.go.kr/wkbikl/ wkbik1312.leaf?hback $=$ true $\&$ plntIlstrNo=24409\#. UdoDCTsvnTo. Accessed 8 July 2013. (in Korean)

Lee CB. 2003. Colored Flora of Korea. Hyangmoonsa, Seoul. (in Korean)

Lee S, Ma S, Lim Y, Choi HK, Shin H. 2004. Genetic diversity and its implications in the conservation of endangered Zostera japonica in Korea. J Plant Biol 47: 275-281.

Milella L, Saluzzi D, Lapelosa M, Bertino G, Spada P, Greco I, Martelli G. 2006. Relationships between an Italian strawberry ecotype and its ancestor using RAPD mark- 
ers. Genet Resour Crop Ev 53: 1715-1720.

Min SJ, Kim HT, Kim JG. 2012. Assessment of genetic diversity of Typha angustifolia in the development of cattail stands. J Ecol Field Biol 35: 27-34.

Mulligan GA, Munro DB. 1981. The biology of Canadian weeds: 48. Cicuta maculata L., C. douglasii (DC.) Coult. \& Rose and C. virosa L. Can J Plant Sci 61: 93-105.

Nei M. 1973. Analysis of gene diversity in subdivided populations. Proc Natl Acad Sci USA 70: 3321-3323.

Newbury HJ, Ford-Lloyd BV. 1993. The use of RAPD for assessing variation in plants. Plant Growth Reg 12: 43-51.

Ok GH, Yoo KO. 2012. Habitats ecological characteristics of Asplenium scolopendrium L. and its RAPD Analysis. Korean J Plant Res 25: 719-730.

Panter KE, Keeler RF, Baker DC. 1988. Toxicoses in livestock from the hemlocks (Conium and Cicuta spp.). J Anim Sci 66: 2407-2413.

R Development Core Team. 2013. R: a language and environment for statistical computing. R Foundation for Statistical Computing, Vienna, Austria. URL http://www.Rproject.org/. Accessed 8 July 2013.

Ray T, Roy SC. 2009. Genetic diversity of Amaranthus species from the Indo-Gangetic plains revealed by RAPD analysis leading to the development of ecotype-specific SCAR marker. J Hered 100: 338-347.
Sarreveld E, Hope E. 1975. Cicutoxin poisoning (water hemlock). Neurology 25: 730-734.

Shin CJ, Nam JM, Kim JG. 2013. Comparison of environmental characteristics at Cicuta virosa habitats, an endangered species in South Korea. J Ecol Environ 36: 19-30.

Shin CJ, Kim JG. 2013. Ecotypic differentiation in seed and seedling morphology and physiology among $\mathrm{Ci}$ cuta virosa populations. Aquat Bot. DOI 10.1016/j. aquabot.2013.06.005.

Strauß U, Wittstock U, Schubert R, Teuscher E, Jung S, Mix E. 1996. Cicutoxin from Cicuta virosa: a new and potent potassium channel blocker in T Lymphocytes. Biochem Biophys Res Commun 219: 332-336.

Tatar S. 2010. Seed longevity and germination characteristics of six fen plant species. Acta Biol Hung 61: 197-205.

Virk PS, Ford-Lloyd BV, Jackson MT, Newbury HJ. 1995. Use of RAPD for the study of diversity within plant germplasm collections. Heredity 74: 170-179.

Williams JGK, Kubelik AR, Livak KJ, Rafalski JA, Tingey SV. 1990. DNA polymorphisms amplified by arbitrary primers are useful as genetic markers. Nucleic Acids Res 18: 6531-6535.

Yeh FC, Boyle TJB. 1997. Population genetic analysis of codominant and dominant markers and quantitative traits. Belg J Bot 129: 157. 